DOI: https://doi.org/10.31933/jemsi.v3i2 Received: 8 September 2021, Revised: 15 Oktober 2021, Publish: 30 November 2021

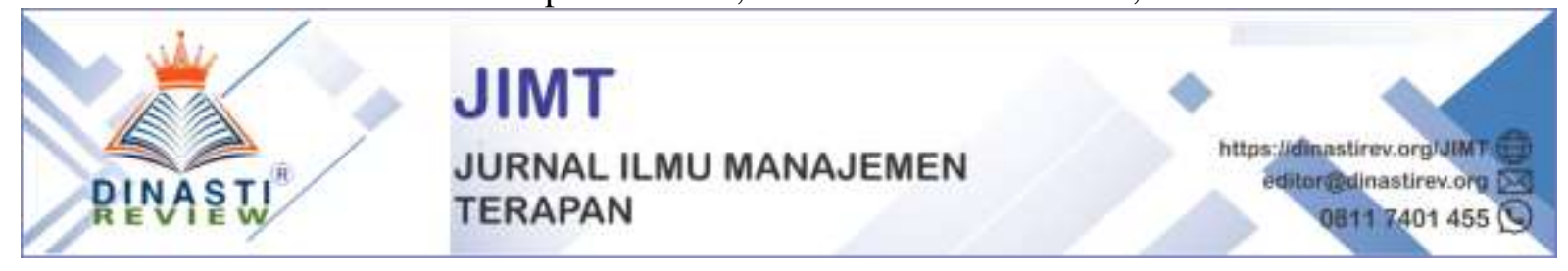

\title{
MODEL KEPUTUSAN PEMBELIAN RUMAH SUBSIDI DARI PERSPEKTIF FASILITAS, CITRA PERUSAHAAN DAN HARGA (SURVEY PADA PERUMAHAN PANORAMA SAKURAN ASRI KOTA JAMBI)
}

\author{
Akhmad Irwansyah Siregar ${ }^{1}$ \\ ${ }^{1)}$ Dosen Fakultas Ekonomi Universitas Batanghari, Jambi, Indonesia, email: \\ akhmad.irwansyah.siregar@unbari.ac.id
}

\section{Corresponding Author: Akhmad Irwansyah Siregar}

Abstrak: Penelitian ini bertujuan untuk menganalisis pengaruh fasilitas, citra perusahaan dan harga terhadap keputusan pembelian konsumen pada rumah subsidi baik secara parsial maupun simultan pada Perumaha Panorama Sakura Asri Kota Jambi. Populasi dalam penelitian ini adalah konsumen rumah subsidi pada Perumahan Panorama Sakura Asri Kota Jambi dengan jumlah populasi 173 konsumen. Ukuran sampel pada penelitian ini ditentukan melalui formula Slovin dengan error margin 10\%, sehingga diperoleh sampel penelitian sebanyak 64. Pendekatan dalam penelitian ini menggunakan pendekatan kuantitatif dengan metode survey dan menggunakan analisis data persamaan regresi linier berganda yang dibantu dengan software SPSS 21.0 for windows. Namun sebelum dilakukan analisis, terlebih dahulu dilakukan uji kualitas data melalui uji validitas dan reliabilitas serta uji asumsi klasik. Kemudian uji hipotesis melalui uji F (simultan) dan uji t (parsial). Dari hasil analisis disimpulkan bahwa fasilitas, citra perusahaan dan harga secara bersama-sama berpengaruh positive dan signifikan terhadap keputusan pembelian konsumen. Artinya semakin baik fasilitas yang diberikan oleh perusahaan pada konsumennya, yang didukung pula dengna citra perusahaan yang baik, serta didukung pula dengan tingkat kesesuaian harga yang diberikan, maka hal ini akan semakin meningkatkan keputusan konsumen dalam membeli rumah subsidi.

Kata Kunci: Fasilitas, Citra Perusahaan, Harga, dan Keputusan Pembelian.

\section{PENDAHULUAN}

Salah satu kebutuhan manusia yang mendasar adalah masalah rumah. Rumah sebagai tempat tinggal adalah salah satu kebutuhan pokok manusia selain pakaian dan makanan. Tiap manusia membutuhkan rumah untuk tempat berlindung dan sebagai tempat berkumpul dan berlangsungnya aktivitas keluarga. Sekaligus sebagai sarana investasi. Fungsi rumah juga telah berubah, dari yang semula hanya sekedar sebagai tempat berlindung. Kini sebuah rumah tak cukup hanya untuk berteduh namun juga dituntut untuk mengakomodir kebutuhan dan keinginan pemiliknya. Seperti lokasi yang stategis, bangunan yang bagus \& kokoh, dan lingkungannya yang nyaman. Dengan kata lain tak cukup hanya asal untuk berteduh namun juga harus bisa menjadi tempat tinggal yang layak (Primananda, 2010). 
Perumahan dan pemukiman mempunyai fungsi strategis dalam perannya sebagai pusat pendidikan keluarga, persemaian budaya, dan peningkatan kualitas generasi yang akan datang serta merupakan pengejawantahan jati diri bangsa, disamping sebagai pelindung terhadap gangguan alam atau cuaca. Terwujudnya kesejahteraan masyarakat dan sumber daya manusia yang berkualitas dapat ditandai dengan meningkatnya kualitas kehidupan yang layak huni (Widiastuti dan Handayani, 2013).

Menurut Kimtaru (2004) bahwa kebutuhan akan perumahan pada dasarnya dapat dibagi atas dua hal pokok, yaitu: Kebutuhan akan perumahan berdasar tren (kecenderungan) pertumbuhan penduduk secara alamiah serta kebutuhan dan penyediaan rumah berdasarkan atas banyaknya rumah layak huni. Berdasar poin kedua di atas sesuai dengan kebutuhan akan perumahan berdasar kebutuhan dan penyediaan rumah berdasarkan atas banyaknya rumah layak huni banyak pengembang properti perumahan yang menawarkan perumahan bersubsidi dengan bekerjasama dengan bank pemerintah, seperti Bank Negara Indonesia dan Bank Tabungan Negara dalam pendanaannya dengan sasaran masyarakat berpendapatan menengah ke bawah.

Dengan melihat kondisi seperti ini mendorong produsen untuk melebarkan sayapnya di bidang perumahan. Maka tidak mengherankan jika akhir-akhir ini bisnis di bidang perumahan semakin marak, banyak perusahaan muncul dengan memberikan berbagai macam fasilitas dalam menawarkan produknya. Perkembangan bisnis perumahan semakin marak dewasa ini, tidak hanya terpusat di kota-kota besar akan tetapi sudah meluas di kota-kota kecil.

Secara teori terdapat banyak faktor yang dapat mempengaruhi keputusan pembelian konsumen. Namun pada penelitian ini penulis mencoba melihat faktor-faktor tersebut dari perspektif fasilitas, citra perusahaan dan harga. Hal ini didasari dari survey yang dilakukan, tiga faktor tersebut memiliki peran yang besar terhadap keputusan konsumen dalam membeli rumah subsidi.

Fasilitas adalah sarana yang sifatnya mempermudah konsumen untuk melakukan suatu aktivitas. Fasilitas merupakan segala sesuatu yang sengaja disediakan oleh penyedia jasa untuk dipakai serta dinikmati oleh konsumen yang bertujuan memberikan tingkat kepuasan yang maksimal. Fasilitas merupakan segala sesuatu yang bersifat peralatan fisik yang disediakan oleh pihak penjual jasa untuk mendukung kenyamanan konsumen (Kotler \& Amstrong, 2016). Fasilitas dalam perusahaan jasa merupakan faktor yang menentukan pilihan orang untuk membeli sebuah produk (Tjiptono dan Chandra, 2016).

Pentingnya fasilitas terhadap keputusan pembelian juga dikemukakan oleh Iskandar dan Sumiyati (2018); Imalia dan Aprileny (2020); dan Sugianto dan Ginting (2020) dalam penelitiannya yang mengungkapkan bahwa fasilitas memberikan pengaruh yang positif dan signifikan terhadap keputusan pembelian konsumen. Artinya semakin baik fasilitas yang diberikan oleh perusahaan terhadap konsumennya, maka keputusan pembelian konsumenpun akan semakin meningkat pula. Sehingga sangatlah penting bagi perusahaan pengembang untuk dapat memberikan fasilitas umum maupun fasilitas social bagi para pembeli rumah. Selain itu fasilitas menjadi penting karena fasilitas adalah sumber daya fisik yang harus ada sebelum jasa ditawarkan kepada konsumen. Namun hasil ini tidak sejalan dengan penelitian yang dilakukan oleh Memah dkk (2015) yang mengemukakan bahwa fasilitas tidak memiliki pengaruh terhadap keputusan pembelian konsumen.

Faktor berikutnya yang menjadi keputusan konsumen dalam membeli rumah subsidi berdasarkan survey yang dilakukan adalah citra perusahaan. Citra perusahaan yang baik akan memberikan dorongan kepada konsumen untuk menjalin ikatan yang kuat dengan perusahaan. Selanjutnya ikatan tersebut memungkinkan perusahaan untuk lebih memahami secara seksama keinginan serta kebutuhan konsumen, sehingga dapat memenuhi keinginan dan kebutuhan konsumen (Tjiptono dan Chandra, 2016). 
Menurut Prabowo dkk (2014) dalam penelitiannya mengungkapkan bahwa salah satu strategi untuk memenangkan persaingan adalah strategi membangun citra perusahaan. Sebuah keharusan bagi perusahaan untuk mampu membangun citra perusahaan yang baik dimata pelanggan maupun publik. Lebih lanjut Weiwei dalam Prabowo dkk (2014) menyatakan bahwa citra perusahaan adalah kesan-kesan yang dimiliki oleh publik terhadap perusahaan. Beberapa penelitian yang telah dilakukan sebelumnya juga menemukan bahwa citra perusahaan memiliki pengaruh terhadap keputusan pembelian konsumen diantaranya yaitu, Pratiwi dan Widiyastuti (2018); Prabowo dkk (2014); Lesmana dan Yustriani (2017); dan Legautu, dkk (2019). Namun bertentangan dengan penelitian yang dilakukan oleh Nasution (2019) dan Melisa dkk (2014) yang mengemukakan bahwa citra perusahaan tidak memiliki pengaruh terhadap keputusan pembelian konsumen.

Selain fasilitas dan citra perusahaan, adapun faktor berikutnya yang mempengaruhi keputusan pembelian konsumen dalam membeli rumah subsidi berdasarkan survey yang dilakukan adalah harga. Harga merupakan salah satu keputusan yang harus dipertimbangkan konsumen sebelum membeli suatu produk. Jika harga produk yang ditawarkan produsen ke konsumen tidak sesuai dengan kualitasnya, hal ini akan membuat konsumen kecewa dan berfikir ulang untuk membeli produk tersebut (Setiadi, 2015).

Harga adalah sesuatu hal yang penting, karena harga sangat berhubungan dengan keputusan seseorang untuk membeli suatu produk. Ketika mendengar sebuah produk yang dijual dengan harga murah, pasti para konsumen akan berbondong-bondong lari dan berebutan untuk mendapatkan produk tersebut. Itulah sebabnya mengapa harga sangat berperan dalam menentukan keputusan seseorang untuk membeli suatu produk (Marwanto, 2015). Hal ini sejalan dengan hasil penelitian yang dilakukan oleh Memah dkk (2015) yang mengemukakan bahwa harga memiliki peranan yang besar terhadap keputusan konsumen untuk membeli ataupun tidak membeli sebuah rumah. Kemudian Sugianto dan Ginting (2020) dalam penelitiannya mengemukakan bahwa pentingnya penetapan harga perumahan yang dapat dilihat dari variasi harga rumah berdasarkan luas tanah dan bangunannya sehingga konsumen dapat memilih dan menyesuaikan pada tingkat harga mana yang kesanggupannya. Namun hasil ini tidak sejalan dengan penelitian yang dilakukan oleh Munthe, P. (2020) yang mengemukakan bahwa harga tidak memiliki pengaruh terhadap keputusan pembelian konsumen.

Adanya beberapa gap berdasarkan teori dan penelitian yang telah dilakukan sebelumnya, maka menarik bagi penulis untuk melakukan kajian lebih lanjut dengan menganilisis pengaruh fasilitas, citra perusahaan dan harga terhadap keputusan pembelian rumah subsidi.

\section{KAJIAN PUSTAKA \\ Keputusan Pembelian}

Pengambilan keputusan merupakan suatu kegiatan individu yang secara langsung terlibat dalam mendapatkan dan mempergunakan barang yang ditawarkan. Menurut Setiadi (2015) mendefinisikan suatu keputusan (decision) melibatkan pilihan diantara dua atau lebih alternatif tindakan atau perilaku. Keputusan selalu mensyaratkan pilihan diantara beberapa perilaku yang berbeda. Menurut Kotler dan Keller (2012) keputusan pembelian adalah tahap dalam proses pengambilan keputusan pembeli di mana konsumen benar-benar membeli. Pengambilan keputusan merupakan suatu kegiatan individu yang secara langsung terlibat dalam mendapatkan dan mempergunakan barang yang ditawarkan. Menurut Schiffman dan Kanuk (2008) keputusan adalah seleksi-seleksi terhadap dua pilihan alternatif atau lebih. Menurut Peter dan Olson (2013) suatu keputusan (decision) mencakup suatu pilihan diantara 
dua atau lebih tindakan (atau perilaku) alternatif. Peter dan Olson (2013) pengambilan keputusan konsumen (consumer decision making) adalah proses integrasi yang digunakan untuk mengkombinasikan pengetahuan untuk mengevaluasi dua atau lebih perilaku alternative dan memilih satu diantaranya.

Menurut Sunyoto (2015) Setiap keputusan pembelian mempunyai suatu struktur sebanyak tujuh. Indikator tersebut adalah 1) Keputusan tentang jenis produk; 2) Keputusan tentang bentuk produk; 3) Keputusan tentang merek; 4) Keputusan tentang penjualnya; 5) Keputusan tentang jumlah produk; 6) Keputusan tentang waktu pembelian; dan 7) Keputusan tentang pembayaran. Sedangkan menurut Kotler, P (2012) terdapat 4 indikator dari keputusan pembelian yaitu: 1) Kemantapan pada sebuah produk; 2) Kebiasan dalam membeli produk; dan 3) Memberikan rekomendasi kepada orang lain.

\section{Fasilitas}

Fasilitas merupakan bentuk fisik atau atmosfir yang dibentuk oleh eksterior dan interior yang disediakan dalam membangu rasa aman dan nyaman pelanggan (Tjiptono dan Chandra, 2016). Menurut Kotler (2012) mendefisnisikan fasilitas sebagai segala sesuatu yang bersifat peralatan fisik dan disediakan oleh penjual jasa untuk kenyaman konsumen.Fasilitas merupakan sesuatu yang sangat penting dalam usaha jasa, oleh karena itu fasilitas yang ada yaitu kondisi fasilitas, kelengkapan desain interior dan eksterior serta kebersihan fasilitas harus dipertimbangkan terutama yang berkaitan erat dengan apa yang dirasakan konsumen secara langsung. Fasilitas merupakan suatu bentuk kebendaan yang berfungsi untuk menambah nilai suatu produk atau layanan jasa. Menurut Lupiyoadi, (2013) Fasilitas merupakan penampilan, kemampuan sarana prasarana dan keadaan lingkungan sekitarnya dalam menunjukkan eksistensinya kepada eksternal yang meliputi fasilitas fisik (gedung) perlengkapan dan peralatan.

Menurut Sumayang (2003) menjelaskan bahwa fasilitas adalah penyediaan perlengkapan fisik yang memberikan kemudahan kepada konsumen untuk melakukan aktivitasnya sehingga kebutuhan konsumen dapat terpenuhi. Lebih lanjut Sumayang (2003) menyatakan bahwa ada beberapa hal yang perlu diperhatikan dalam penyediaan fasilitas yang dapat dijadikan pengukuran fasilitas, yaitu: 1) Kelengkapan, kebersihan, dan kerapian fasilitas yang ditawarkan adalah keadaan fasilitas perusahaan yang dilengkapi oleh atribut yang menyertainya dan didukung dengan kebersihan dan kerapian saat konsumen menggunakan fasilitas tersebut; 2) Kondisi dan fungsi fasilitas yang akan ditawarkan adalah fasilitas yang berfungsi dengan baik dan tidak mengalami kerusakan; dan 3) Kemudahan menggunakan fasilitas yang ditawarkan adalah fasilitas yang ditawarkan kepada konsumen adalah fasilitas yang sudah familier bagi konsumen sehingga konsumen dapat menggunakannya dengan mudah.

\section{Citra Perusahaan}

Citra perusahaan adalah respon pelanggan pada keseluruhan penawaran yang diberikan perusahaan dan didefinisikan sebagai sejumlah kepercayaan, ide-ide, dan kesan masyarakat pada suatu perusahaan Kotler (2012). Menurut Davies et al dalam Pratiwi dan Widiyastuti, 2018) citra perusahaan merupakan pesan keseluruhan yang terbentuk dibenak masyarakat tentang perusahaan, dimana perusahaan tersebut berhubungan dengan nama bisnis, arsitektur,variasi dari produk, tradisi, ideologi dan kesan pada kualitas komunikasi yang dilakukan oleh setiap karyawan yang berinteraksi dengan klien organisasi.

Steinmentz (2011) menyatakan bahwa citra perusahaan sebagai persepsi masyarakat terhadap jati diri perusahaan. Citra perusahaan tidak bisa direkayasa, artinya citra tidak datang dengan sendirinya melainkan dibentuk oleh masyarakat, citra perusahaan yang positif dapat dibangun dengan melakukan komunikasi dan keterbukaan kepada masyarakat. Upaya 
membangun citra tidak bisa dilakukan secara singkat, tetapi merupakan suatu proses yang membutuhkan waktu cukup lama. Karena citra merupakan semua persepsi atas objek yang dibentuk oleh pelanggan dengan cara memproses informasi dari berbagai sumber sepanjang waktu.

Menurut Harrison (2010) citra perusahaan terbentuk meliputi empat elemen, yaitu: 1) Personality; 2) Reputation; 3) Value/ethics; dan 4) Corporate identity. Aspek-aspek tersebut merupakan hal yang dapat ditangkap oleh konsumen dan menimbulkan kesan dan persepsi konsumen terhadap perusahaan. Sedangkan menurut Zhang (2009) citra perusahaan dapat diukur melalui: 1) Disukai (Likeability); 2) Kompetensi (Competence); 3) Kualitas (Quality); 4) Kinerja (Performance); dan 5) Tanggung Jawab (Responsibility).

\section{Harga}

Harga adalah apa yang harus diberikan oleh konsumen (pembeli) untuk mendapatkan suatu produk (Lamb et al., 2001). Sedangkan menurut Kotler dan Amstrong (2016) harga adalah sejumlah uang yang dibebankan atas suatu produk atau jasa, atau jumlah dari nilai yang ditukar konsumen atas manfaat manfaat karena memiliki atau menggunakan produk atau jasa tersebut Harga merupakan elemen yang paling fleksibel di antara keempat elemen bauran pemasaran. Menurut Tjiptono dan Tjandra (2016) secara sederhana istilah harga dapat diartikan sebagai jumlah uang (satuan moneter) dan/atau aspek lain (non moneter) yang mengandung utilitas/kegunaan tertentu yang diperlukan untuk mendapatkan suatu jasa. Demikian halnya menurut Kotler (2012) Penetapan harga dan persaingan harga merupakan masalah nomor satu yang dihadapi oleh para eksekutif pemasaran.namun, banyak perusahaan tidakmampu menangani penetapan harga dengan baik. Perilaku konsumen dalam membeli rumah pasti membandingkan harga dengan perumahan lain. Bagaimana fasilitas, lingkungan, lokasi, dan yang palingpenting harganya.Apalagi sekarang pengembang menawarkan berbagai macam tipe perumahan, dengan berbagai macam fasilitas, dan hadiah.

Menurut Rahma dalam Munthe (2020) pertimbangkan pembeli terhadap harga sebuah rumah didasarkan pada: 1) Kesesuaian/keterjangkauan harga oleh segmentasi yang dituju; 2) Kesesuaian harga dengan manfaat yang diterima;dan 3) Kesesuaian harga dengan kualitas rumah yang diinginkan. Sedangkan menurut Stanton (2008) dimensi yang digunakan untuk mengukur harga yaitu: 1) Keterjangkauan harga; 2) Kesesuaian harga dengan kualitas produk; 3) Daya saing harga; dan 4) Kesesuaian harga dengan manfaat.

\section{Kerangka Berpikir}

Dari beberapa kajian penelitian terdahulu berdasarkan kasus, objek dan unit analisis riset, maka riset terdahulu yang menjadi acuan untuk riset ini adalah sebagai berikut:

1) Fasilitas $\left(X_{1}\right)$ berpengaruh terhadap keputusan pembelian $(Y)$, berdasarkan hasil riset: Imalia dan Aprileny (2020); Iskandar dan Sumiyati (2018); dan Sugianto dan Ginting (2020), dimana fasilitas berpengaruh positif dan signifikan terhadap keputusan pembelian baik secara parsial maupun secara simultan.

2) Citra perusahaan $\left(\mathrm{X}_{2}\right)$ berpengaruh terhadap keputusan pembelian $(\mathrm{Y})$, berdasarkan hasil riset: Pratiwi dan Widiyastuti (2018); Prabowo dkk (2014); Lesmana dan Yustriani (2017); dan Legautu, dkk (2019), dimana citra perusahaan berpengaruh positif dan seignifikan terhadap keputusan pembelian baik secara parsial maupun secara simultan.

3) Harga $\left(X_{3}\right)$ berpengaruh terhadap keputusan pembelian (Y), berdasarkan hasil riset: Memah dkk (2015); Iskandar dan Sumiyati (2018); dan Sugianto dan Ginting (2020), dimana harga berpengaruh positif dan seignifikan terhadap keputusan pembelian baik secara parsial maupun secara simultan. 
Dari kajian teori dan riset terdahulu dan berdasrkan tujuan riset maka rerangka riset ini adalah seperti di bawah ini.

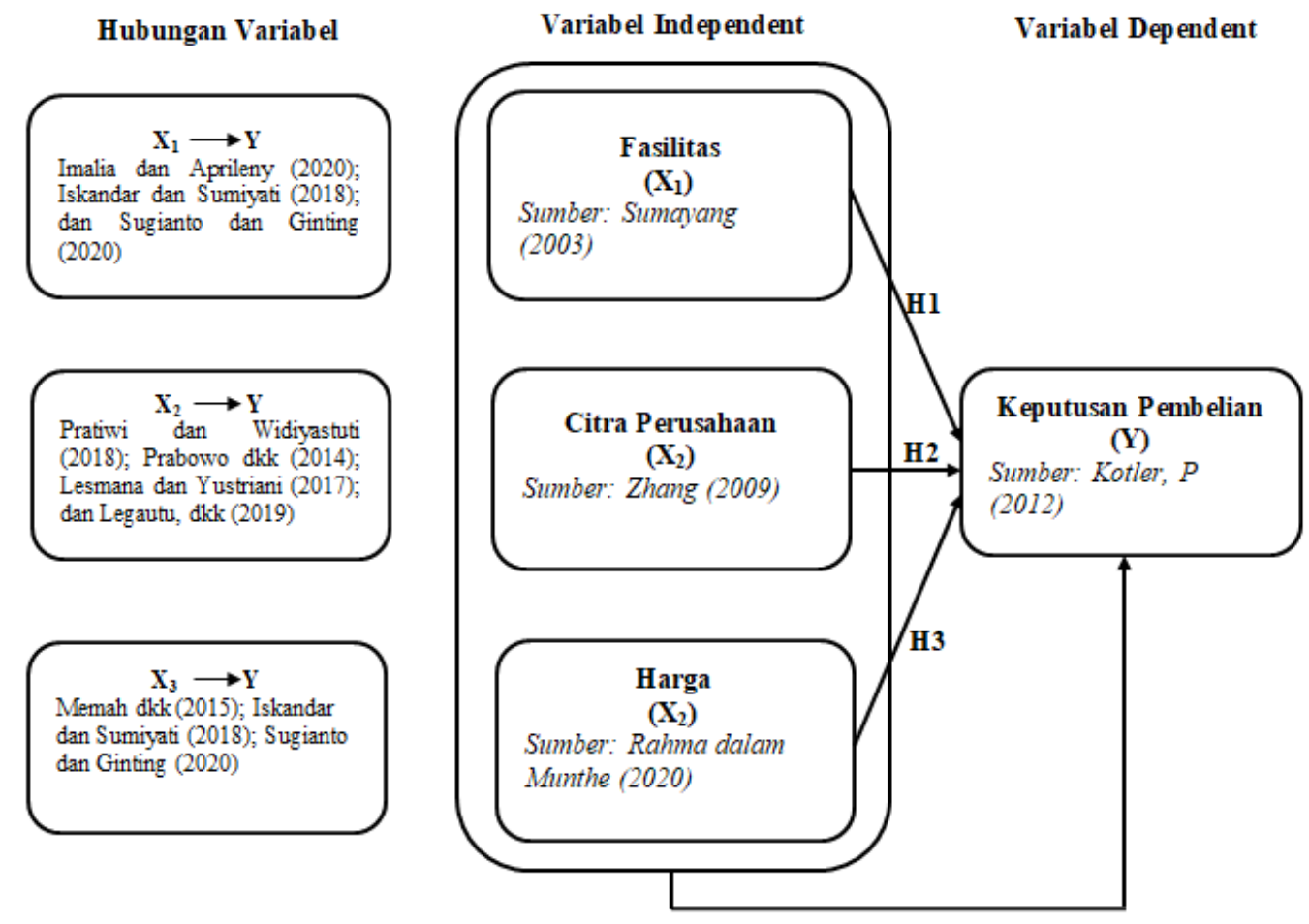

Gambar 1: Kerangka Pemikiran

Berdasarkan tujuan penelitian dan tinjauan teori maka Hipotesis penelitian adalah:

1) Fasilitas berpengaruh terhadap keputusan pembelian rumah sibsidi;

2) Citra perusahaan berpengaruh terhadap keputusan pembelian rumah sibsidi;

3) Harga berpengaruh terhadap keputusan pembelian rumah sibsidi;

4) Fasilitas, citra perusahaan dan harga secara bersama-sama berpengaruh terhadap keputusan pembelian rumah sibsidi.

\section{METODE PENELITIAN}

Unit analisis pada penelitian ini adalah konsumen rumah subsidi pada Perumahan Panorama Sakura Asri Kota Jambi dengan jumlah populasi 173 konsumen. Ukuran sampel pada penelitian ini ditentukan melalui formula Slovin dengan error margin 10\%, sehingga diperoleh sampel penelitian sebanyak 64 .

Penelitian ini merupakan penelitian kuantitatif, karena data yang diperoleh berupa angka. Jenis penelitiannya adalah kuesioner dan metode yang digunakan tentang fenomena yang terjadi, prosesnya berupa pengumpulan dan penyusunan data serta analisis data. Data dikumpulkan melalui pengisian kuesioner dan dianalisis lebih lanjut. Penelitian ini terdiri atas 4 (empat variabel), yaitu variabel eksogen (fasilitas, citra perusahaan dan harga), terhadap variabel endogen keputusan pembelian.

Untuk menjawab semua tujuan pada penelitian ini, penulis menggunakan persamaan regresi linear berganda sebagai teknik analisis, dengan formula $Y=a+b_{1} X_{1}+b_{2} X_{2}+$ $b_{3} X_{3}+e=$, dimana $\mathrm{Y}$ adalah variable keputusan pembelian, koefisien $\mathrm{b}_{1}, \mathrm{~b}_{2}$ dan $\mathrm{b}_{3}$ adalah variable fasilitas $\left(\mathrm{X}_{1}\right)$, citra perusahaan $\left(\mathrm{X}_{2}\right)$, dan harga $\left(\mathrm{X}_{3}\right)$. Guna mempermudah proses analisis data pada penelitian ini, penulis menggunakan aplikasi SPSS versi 21.0 for windows sebagai alat bantu analisis. 
Setelah data diproses, langkah selanjutnya yaitu melakukan uji hipotesis melalui uji t untuk melakukan pengujian hipotesi secara parsial, dan uji $\mathrm{F}$ untuk melakukan pengujian secara simultan, dengan margin error yang ditetapkan sebesar 5\%. Namun sebelum dilakukan pengujian hipotesis, terlebih dahulu dilakukan uji instrument penelitian melalui uji validitas dan uji reliabilitas, serta melakukan uji asumsi klasik melalui uji normalitas, multikolinearitas, dan heterokedastisitas.

\section{HASIL DAN PEMBAHASAN Hasil}

Statistik deskriptif yang digunakan adalah nilai rata-rata (mean), nilai yang sering muncul pada jawaban responden (modus), nilai tengah (median), simpangan baku (standar deviasi) serta varians sampel. Adapun hasil statistik deskriptif dalam penelitian dengan menggunakan alat bantu SPSS 21.0 sebagai berikut:

Tabel 1 : Statistik Deskriptif Variabel Penelitian

\begin{tabular}{|c|c|c|c|c|}
\hline & X1_Fasilitas & $\begin{array}{l}\text { X2_Citra_ } \\
\text { Perusahaan }\end{array}$ & X3_Harga & $\begin{array}{l}\text { Y_Kep_ } \\
\text { Pembelian }\end{array}$ \\
\hline $\begin{array}{l}\text { N } \quad \text { Valid } \\
\text { Mean } \\
\text { Std. Error of Mean } \\
\text { Median } \\
\text { Mode } \\
\text { Std. Deviation } \\
\text { Variance } \\
\text { Range } \\
\text { Minimum } \\
\text { Maximum } \\
\text { Sum }\end{array}$ & $\begin{array}{r}64 \\
0 \\
3,5313 \\
, 06109 \\
3,6667 \\
3,67 \\
, 48874 \\
, 239 \\
2,00 \\
2,33 \\
4,33 \\
226.00\end{array}$ & $\begin{array}{r}64 \\
0 \\
3,4969 \\
, 04272 \\
3,4000 \\
3,40 \\
, 34178 \\
, 117 \\
1,60 \\
2,60 \\
4,20 \\
223,80\end{array}$ & $\begin{array}{r}64 \\
0 \\
3,5521 \\
, 06481 \\
3,6667 \\
3,67 \\
, 51851 \\
, 269 \\
2,33 \\
2,00 \\
4,33 \\
227,33\end{array}$ & $\begin{array}{r}64 \\
0 \\
3,3958 \\
, 05499 \\
3,3333 \\
3,67 \\
, 43996 \\
, 194 \\
2,00 \\
2,33 \\
4,33 \\
217,33\end{array}$ \\
\hline
\end{tabular}

Sumber: Output SPSS 21.0

Sebelum melangkah ke pengujian hipotesis, terlebih dahulu harus melalui perhitungan persyaratan analisis. Pengujian persyaratan analisis haruslah terpenuhinya asumsi klasik. Untuk mendapatkan nilai pemeriksa yang efisien dan tidak bias atau BLUE (Best Linear Unbias Estimator) dari satu persamaan regresi berganda dengan metode kuadrat terkecil (least square), maka perlu dilakukan pengujian untuk mengetahui model regresi yang dihasilkan memenuhi persyaratan asumsi klasik. Dalam penelitian ini akan di kemukakan uji asumsi klasik yang umum digunakan, yaitu Uji Normalitas Uji Muktikolinearitas dan Uji Heterokedastisitas.

Dari hasil uji yang dilakukan dengan menggunkan bantuan SPSS 21.0 sebagai alat bantu dalam penelitian ini diperoleh hasil bahwasanya data dalam penelitian ini berdistribusi normal, hal ini dibuktikan dari hasil nilai signifikansi (Asymp. Sig. 2-tailed) lebih besar dari 0,05 , yaitu $(0,479>0,05)$ sehingga dapat disimpulkan bahwa data dalam penelitian ini berdistribusi normal.

Kemudian dari hasil uji multikolinearitas diketahui bahwasanya hasil perhitungan nilai Tolerance menunjukan tidak ada variabel independent yang memiliki nilai Tolerance kurang dari 0.10, yang berarti tidak ada korelasi antar variabel independent. Selain itu pula hasil perhitungan nilai Variance Inflation Factor (VIF) juga menunjukan hal yang sama tidak ada satu variabel independent yang memiliki nilai VIF lebih dari 10. Jadi dapat disimpulkan bahwa tidak terjadi multikolinearitas antar variabel Independent dalam model regresi. 
Selanjutnya dari hasil uji heterokedastisitas diketahui scatterplots terlihat bahwa titiktitik menyebar secara acak serta tresebar baik diatas maupun dibawah angka 0 pada sumbu Y. hal ini dapat disimpulkan bahwa tidak terjadi heterokedastisitas pada model regresi, sehingga model regresi layak dipakai untuk memprediksi Penggunaan jasa akomodasi berdasarkan masukan variabel independent.

Dari hasil uji asumsi yang dilakukan semuanya telah terpenuhi, sehingga model persamaan regresi dianggap baik dan dapat dilanjutkan untuk tahap berikutnya, yaitu dengan melakukan uji regresi dan pengujian hipotesis. Adapun dari pengolahan data yang dilakukan dengan menggunakan SPSS 21.0 for windows, di peroleh outputnya sebagai berikut.

Tabel 2: Hasil Analisa Regresi Linear Berganda

\begin{tabular}{|c|c|c|c|c|c|}
\hline $\begin{array}{l}\text { Variabel } \\
\text { Terikat }\end{array}$ & Variabel Bebas & $\begin{array}{c}\text { Koefisien } \\
\text { Regresi }\end{array}$ & $\mathbf{t} / \mathbf{F}_{\text {hitung }}$ & Sig. & $\begin{array}{c}\text { Keputusan } \\
\text { Hipotesis }\end{array}$ \\
\hline \multirow{8}{*}{$\begin{array}{c}\text { Keputusan } \\
\text { Pembelian } \\
\text { (Y) }\end{array}$} & Konstanta (a) & 2,140 & & & - \\
\hline & Fasilitas $\left(\mathrm{X}_{1}\right)$ & 0,294 & 2,329 & 0,023 & Diterima \\
\hline & Citra Perusahaan $\left(\mathrm{X}_{2}\right)$ & 0,068 & 0,955 & 0,353 & Ditolak \\
\hline & Harga $\left(\mathrm{X}_{3}\right)$ & 0,351 & 2,904 & 0,005 & Diterima \\
\hline & $\mathrm{F}$ & & 22,060 & 0,000 & Diterima \\
\hline & Adjusted $\mathrm{R}^{2}$ & \multicolumn{4}{|r|}{0,501} \\
\hline & $\mathrm{t}_{\text {tabel }}$ & \multicolumn{4}{|r|}{1,999} \\
\hline & $\mathrm{F}_{\text {tabel }}$ & \multicolumn{4}{|r|}{2,75} \\
\hline
\end{tabular}

Source: Output SPSS 21.0 for windows.

Dari tabel $1 \mathrm{di}$ atas diperoleh hasil persamaan regresi linear berganda : $Y=\alpha+$ $\beta_{1} X_{1}+\beta_{2} X_{2}+e=2,140+0,294 . X_{1}+0,068 . X_{2}+0,351 . X_{3}+$ e. Keterangan: $Y=$ Keputusan pembelian; $X_{1}=$ fasilitas; $X_{2}=$ citra perusahaan; dan $X_{3}=$ harga. Dari persamaan ini dapat diinterpretasikan:

1) Dari hasil persamaan regresi di atas diperoleh nilai konstanta sebesar 2,140. Nilai tersebut memiliki makna bahwa jika variabel independent (fasilitas, citra perusahaan dan harga) bersifat konstans atau tidak berlangsung dengan baik maka nilai keputusan pembelian konsumen sebesar 2,140 skala/satuan.

2) Dari hasil persamaan regresi di atas pula diperoleh nilai koefisien fasilitas sebesar 0,294 . Nilai tersebut menunjukan bahwa setiap penambahan satu nilai fasilitas akan menaikan nilai keputusan pembelian sebesar 0,294, atau dengan kata lain apabila fasilitas semakin baik, maka hal itu akan diikuti pula dengan peningkatan keputusan pembelian konsumen.

3) Selanjutnya masih berdasarkan persamaan regresi di atas diperoleh nilai koefisien citra perusahaan sebesar 0,068. Nilai tersebut memiliki bahwa setiap penambahan satu nilai citra perusahaan akan menaikan nilai keputusan pembelian konsumen sebesar 0,068, atau dengan kata lain apabila citra perusahaan semakin baik, maka hal itu akan diikuti pula dengan peningkatan keputusan pembelian konsumen semakin baik pula.

4) Berikutnya masih berdasarkan persamaan regresi di atas diperoleh nilai koefisien harga sebesar 0,351. Nilai tersebut memiliki makna bahwa semakin sesuai harga yang diberikan pada konsumen, maka hal ini akan semakin meningkatkan keputusan konsumen untuk melakukan pembelian terhadap sebuah produk. Sebaliknya semakin 
tidak sesuai harga yang diberikan akan semakin menurunkan keputusan pembelian konsumen.

5) Kemudian berdasarkan persamaan regresi di atas diperoleh pula Nilai Adjusted $R$ Square sebesar 0,501, yang memiliki makna besarnya kemampuan variabel-variabel independent dalam menjelaskan variasi variabel dependent yaitu sebesar 50,1\%, sedangkan sisanya sebesar 49,9\% dipengaruhi oleh variabel lain yang tidak dimasukan dalam model ini.

\section{Uji Hipotesis dan Pembahasan}

\section{1) Pengaruh Fasilitas Terhadap Keputusan Pembelian Rumah Subsidi}

Dari hasil output SPSS sperti yang tampak pada Tabel 2 yang dilakukan diperoleh angka nilai $t$ hitung variabel $\mathrm{X}_{1}$ lebih besar dari nilai $\mathrm{t}$ tabel $(2,329>1,999)$, dengan tingkat signifikansi sebesar 0,023, dikarenakan angka taraf signifikansi lebih $<0,05(0,023<0,05)$ maka dapat disimpulkan bahwa fasilitas berpengaruh terhadap keputusan pembelian konsumen. Berdasarkan dari penjelasan tersebut oleh karena itu $\mathrm{H}_{0}$ ditolak dan $\mathrm{H}_{1}$ diterima, artinya fasilitas berpengaruh terhadap keputusan pembelian konsumen pada rumah subsidi.

Hasil penelitian mendukung dengan penelitian sebelumnya dari Imalia dan Aprileny (2020); Iskandar dan Sumiyati (2018); dan Sugianto dan Ginting (2020) yang menunjukkan bahwa fasilitas berpengaruh positif dan signifikan terhadap keputusan pembelian konsumen. Namun hasil ini tidak sejalan dengan penelitian yang dilakukan oleh Memah dkk (2015) yang mengemukakan bahwa fasilitas tidak memiliki pengaruh terhadap keputusan pembelian konsumen.

Fasilitas adalah sarana yang sifatnya mempermudah konsumen untuk melakukan suatu aktivitas. Fasilitas merupakan segala sesuatu yang sengaja disediakan oleh penyedia jasa untuk dipakai serta dinikmati oleh konsumen yang bertujuan memberikan tingkat kepuasan yang maksimal. Fasilitas merupakan segala sesuatu yang bersifat peralatan fisik yang disediakan oleh pihak penjual jasa untuk mendukung kenyamanan konsumen (Kotler \& Amstrong, 2016). Fasilitas dalam perusahaan jasa merupakan faktor yang menentukan pilihan orang untuk membeli sebuah produk (Tjiptono dan Chandra, 2016).

Selain itu pentingnya fasilitas terhadap keputusan pembelian juga dikemukakan oleh Iskandar dan Sumiyati (2018) dalam penelitiannya yang mengungkapkan bahwa fasilitas memberikan pengaruh yang positif dan signifikan terhadap keputusan pembelian konsumen. Artinya semakin baik fasilitas yang diberikan oleh perusahaan terhadap konsumennya, maka keputusan pembelian konsumenpun akan semakin meningkat pula. Sehingga sangatlah penting bagi perusahaan pengembang untuk dapat memberikan fasilitas umum maupun fasilitas social bagi para pembeli rumah. Selain itu fasilitas menjadi penting karena fasilitas adalah sumber daya fisik yang harus ada sebelum jasa ditawarkan kepada konsumen.

\section{2) Pengaruh Citra Perusahaan Terhadap Keputusan Pembelian Rumah Subsidi}

Dari hasil output SPSS sperti yang tampak pada Tabel 2 yang dilakukan diperoleh angka nilai $t$ hitung variabel $\mathrm{X}_{2}$ lebih kecil dari nilai t tabel $(0,955<1,999)$, dengan tingkat signifikansi sebesar 0,343, dikarenakan angka taraf signifikansi lebih $>0,05(0,343<0,05)$ maka dapat disimpulkan bahwa citra perusahaan tidak berpengaruh terhadap keputusan pembelian konsumen pada rumah subsidi. Berdasarkan dari penjelasan tersebut oleh karena itu $\mathrm{H}_{0}$ diterima dan $\mathrm{H}_{1}$ ditolak, artinya citra perusahaan tidak berpengaruh terhadap keputusan pembelian konsumen untuk rumah subsidi.

Hasil penelitian ini bertentangan dengan penelitian yang dilakukan oleh Pratiwi dan Widiyastuti (2018); Prabowo dkk (2014); Lesmana dan Yustriani (2017); dan Legautu, dkk (2019), yang menyatakan bahwa citra perusahaan memiliki pengaruh terhadap keputusan pembelian konsumen. Namun penelitian ini sejalan dengan penelitian yang dilakukan oleh 
Nasution (2019) dan Melisa dkk (2014) yang menyatakan bahwa citra perusahaan tidak berpengaruh terhadap keputusan pembelian konsumen. Tidak berpengaruhnya citra perusahaan terhadap keputusan konsumen membeli rumah subsidi pada penelitian ini, dikarenakan berdasarkan survey yang dilakukan citra perusahaan bukanlah menjadi faktor utama bagi kosumen dalam mengambil sebuah keputusan untuk membeli rumah subsidi, Melainkan yang lebih utama adalah fasilitas yang di tawarkan oleh perusahaan seperti fasilitas umum, keamanan, luas tanah dan lain fasilitas lainnya. Bahkan dari survey yang dilakukan, banyak dari konsumen yang telah melakukan pembelian rumah subsidi tidak tahu apa nama perusahaan pengembang dari rumah yang mereka miliki.

Meskipun citra perusahaan tidak berpengaruh pada penelitian ini, akan tetapi citra perusahaan tetaplah harus dibentuk oleh perusahaan, karena citra perusahaan merupakan respon keseluruhan konsumen mengenai penawaran dan sejumlah kepercayaan, ide dan kesan yang dimiliki sebuah perusahaan. Selain itu dengan adanya citra perusahaan dapat membantu konsumen dalam mengidentifikasi perbedaan kualitas perusahaan yang sejenis dalam menentukan pemilihan untuk memenuhi kebutuhannya, citra perusahaan positif yang ada pada perusahaan akan membentuk perasaan yang postif dalam benak konsumen terhadap produk atau jasa dari perusahaan dan mempengaruhi keputusan pembelian (Pratiwi dan Widiyastuti, 2018).

\section{3) Pengaruh Harga Terhadap Keputusan Pembelian Rumah Subsidi}

Dari hasil output SPSS sperti yang tampak pada Tabel 2 yang dilakukan diperoleh angka nilai t hitung variabel $\mathrm{X}_{3}$ lebih besar dari nilai t tabel $(2,904>1,999)$, dengan tingkat signifikansi sebesar 0,005, dikarenakan angka taraf signifikansi lebih $<0,05(0,005<0,05)$ maka dapat disimpulkan bahwa harga berpengaruh terhadap keputusan pembelian konsumen untuk rumah subsidi. Berdasarkan dari penjelasan tersebut oleh karena itu $\mathrm{H}_{0}$ ditolak dan $\mathrm{H}_{1}$ diterima, artinya harga berpengaruh terhadap keputusan pembelian konsumen pada rumah subsidi.

Hasil Penelitian ini mendukung dengan penelitian sebelumnya dari Tawas (2013) yang menunjukkan bahwa harga berpengaruh terhadap keputusan pembelian. Naik turunnya harga akan berpengaruh secara bermakna terhadap keputusan pembelian konsumen. Harga yang meningkat atau menurun mengundang respon positif dari konsumen. Selain itu Memah dkk (2015) juga mengemukakan bahwa harga memiliki peranan yang besar terhadap keputusan konsumen untuk membeli ataupun tidak membeli sebuah rumah. Kemudian Sugianto dan Ginting (2020) dalam penelitiannya mengemukakan bahwa pentingnya penetapan harga perumahan yang dapat dilihat dari variasi harga rumah berdasarkan luas tanah dan bangunannya sehingga konsumen dapat memilih dan menyesuaikan pada tingkat harga mana yang kesanggupannya. Namun hasil ini tidak sejalan dengan penelitian yang dilakukan oleh Munthe, P. (2020) yang mengemukakan bahwa harga tidak memiliki pengaruh terhadap keputusan pembelian konsumen.

Harga merupakan salah satu keputusan yang harus dipertimbangkan konsumen sebelum membeli suatu produk. Jika harga produk yang ditawarkan produsen ke konsumen tidak sesuai dengan kualitasnya, hal ini akan membuat konsumen kecewa dan berfikir ulang untuk membeli produk tersebut (Setiadi, 2015). Harga merupakan bauran harga berkenaan dengan strategi dan taktis seperti tingkat harga, struktur diskon, syarat pembayaran, dan tingkat diskriminasi harga diantara berbagai kelompok pelanggan. Harga adalah sejumlah nilai yang konsumen tukarkan untuk jumlah manfaat dengan memiliki atau menggunakan suatu barang atau jasa. Harga merupakan hal yang paling sensitif bagi konsumen. Menaikkan harga melebihi harga pasar akan mengurangi minat konsumen untuk membeli. Untuk itu perusahaan harus menetapkan harga yang sesuai dengan pasaran dan sesuai dengan kualitas suatu produk. 
Harga bukanlah sesuatu yang tidak penting karena harga ini sangat berhubungan dengan keputusan seseorang untuk membeli suatu produk. Ketika mendengar sebuah produk yang dijual dengan harga murah, pasti para konsumen akan berbondong-bondong lari dan berebutan untuk mendapatkan produk tersebut. Itulah sebabnya mengapa harga sangat berperan dalam menentukan keputusan seseorang untuk membeli suatu produk (Marwanto, 2015). Konsumen akan mempertimbangkan faktor harga sebelum menetapkan keputusannya apakah konsumen sanggup membeli atau tidak. Pentingnya penetapan harga perumahan yang dapat dilihat dari variasi harga rumah berdasarkan luas tanah dan bangunannya sehingga konsumen dapat memilih dan menyesuaikan pada tingkat harga mana yang kesanggupannya (Sugianto dan Ginting, 2020).

\section{4) Pengaruh Fasilitas, Citra Perusahaan dan Harga Secara Simultan Terhadap Keputusan Pembelian.}

Dari uji Anova atau $F$ test seperti yang tampak pada Tabel 2 dengan diperoleh nilai $F_{\text {hitung }}$ sebesar 22,060 dengan tingkat probabilitas $p$-value sebesar 0,000, dikarenakan nilai $F_{\text {hitung }}>F_{\text {tabel }}(22,060>2,75)$ dan angka taraf signifikansi jauh lebih $<0,05(0,000<0,05)$ maka dapat disimpulkan variabel fasilitas, citra perusahaan dan harga secara bersama-sama berpengaruh secara signifikan terhadap variabel keputusan pembelian konsumen pada rumah subsidi. Berdasarkan penjelasan tersebut maka $\mathrm{H}_{0}$ ditolak dan $\mathrm{H}_{1}$ diterima, artinya hal ini membuktikan bahwa fasilitas, citra perusahaan dan harga secara bersama-sama berpengaruh secara signifikan terhadap variabel keputusan pembelian konsumen pada rumah subsidi. Dengan demikian hipotesis keempat diterima.

\section{KESIMPULAN} berikut:

Dari hasil penelitian yang telah dilakukan dapat ditarik beberapa kesimpulan sebagai

1. Fasilitas berpengaruh positive dan signifikan terhadap keputusan pembelian konsumen. Artinya semakin baik fasilitas yang diberikan oleh perusahaan terhadap konsumennya, maka keputusan pembelian konsumenpun akan semakin meningkat pula;

2. Citra perusahaan tidak berpengaruh terhadap keputusan pembelian konsumen pada rumah subsidi. Hal ini dikarenakan citra perusahaan bukanlah menjadi faktor utama bagi kosumen dalam mengambil sebuah keputusan untuk membeli rumah subsidi;

3. Harga berpengaruh positive dan signifikan terhadap keputusan pembelian konsumen. Artinya apabila penetapan harga yang diberikan pada konsumen sesuai dengan harapan konsumen, maka hal ini akan diikuti dengan kemantapan konsumen untuk melakukan pembelian, sebaliknya apabila harga produk yang ditawarkan produsen ke konsumen tidak sesuai dengan kualitasnya, hal ini akan membuat konsumen kecewa dan berfikir ulang untuk membeli produk tersebut;

4. Fasilitas, citra perusahaan dan harga secara bersama-sama berpengaruh positive dan signifikan terhadap keputusan pembelian konsumen. Artinya semakin baik fasilitas yang diberikan oleh perusahaan pada konsumennya, yang didukung pula dengna citra perusahaan yang baik, serta didukung pula dengan tingkat kesesuaian harga yang diberikan, maka hal ini akan semakin meningkatkan keputusan konsumen dalam membeli rumah subsidi.

\section{DAFTAR RUJUKAN}

Hapzi Ali. Nandan Limakrisna. (2013). Metodologi Penelitian ( Petunjuk Praktis Untuk Pemecahan Masalah Bisnis, Penyusunan Skripsi, Tesis, dan Disertasi. In Deeppublish: Yogyakarta. 
Harrison, S. (2010). Marketers Guide To Public Relations. Jakarta: Trans Media pustaka.

Imalia, I dan Aprileny, I. (2020). Pengaruh Harga, Fasilitas Dan Lokasi Terhadap Keputusan Pembelian (Studi Kasus Pembelian Rumah Di Grand Nusa Indah Blok J, Cileungsi Pada PT. Kentanix Supra Internasional). Sekolah Tinggi Ilmu Ekonomi Indonesia.

Iskandar, D.N dan Sumiyati. (2018). Pengaruh Harga, Lokasi dan Fasilitas Terhadap Keputusan Pembelian pada Perumahan Grand Mutiara Village Karawang.

Kotler, P. (2012). Manajemen Pemasaran. Jakarta: Indeks.

Kotler, P \& Amstrong, G. (2016). Prinsip-prinsip Pemasaran. Edisi13. Jilid 1. Jakarta:Erlangga.

Kotler, P \& Keller, K.L. (2012). Manajemen pemasaran, Edisi 12, Jilid 1 \&2, Terjemahan Benyamen Molan. Jakarta: PT.Indah.

Lamb, Hair dan McDaniel. (2001). Pemasaran. Jakarta: PT. Salemba Emban Raya

Legautu, J., Soegoto, A.S., dan Sepang, J.L. (2019). Pengaruh Citra Perusahaan, Kualitas Pelayanan Dan Persepsi Konsumen Terhadap Keputusan Pembelian Pada PT. Matahari Department Store Mantos. Jurnal EMBA, Vol. 7, No. 1.

Lesmana, R dan Yustriani. (2017). Pengaruh Citra Perusahaan Terhadap Keputusan Pembelian Konsumen PT. Garuda Indonesia Tbk. (Persero). JIMF (Jurnal Ilmiah Manajemen Forkamma), Vol.1, No.1.

Lupiyoadi, R. (2013). Manajemen Pemasaran Jasa Berbasis Kompetensi. (Edisi 3). Jakarta: Salemba Empat.

Marwanto, A. (2015). Marketing Sukses, Yogyakarta: Kobis.

Melisa, E.B. Go., Lapian, J., dan Moniharapon, S. (2014). Citra Perusahaan dan Kualitas Pelayanan Pengaruhnya Terahdap Keputusan Menggunakan Jasa pada Sekolah Mengemudi Melati di Manado. Jurnal EMBA, Vol. 2, No. 3.

Memah, D., Tumbel, A., dan Rate, P.V. (2015). Analisis strategi promosi, harga, lokasi, dan fasilitas terhadap keputusan pembelian rumah di citraland manado. Jurnal EMBA: Jurnal Riset Ekonomi, Manajemen, Bisnis dan Akuntansi. Vol. 3, No. 1.

Munthe, P. (2020). Faktor-Faktor Yang Mempengaruhi Pengambilan Keputusan Pembelian Properti (Studi Kasus: Perumahan Cemara Asri). Tesis Universitas Sumatra Utara.

Nasution, S.L. (2019). Pengaruh Citra Perusahaan, Pelayanan, dan Produk Terhadap keputusan Pembelian Konsumen pada Master Cash \& Credit Kota Pinang. ECOBISMA: Jurnal Ekonomi, Bisnis dan Manajemen, Vol. 6, No. 1.

Peter, Paul J. dan Jerry C. Olson. (2013). Perilaku Konsumen dan Strategi Pemasaran. Buku 1 edisi 9. Jakarta: Salemba empat.

Prabowo, Y.W., Apriatni., dan Prabawani, B. (2014). Pengaruh Citra Perusahaan Dan Kualitas Pelayanan Terhadap Keputusan Penggunaan Jasa Pengiriman Paket PT. POS INDONESIA (Studi pada Kantor Pos Johar Kota Semarang).

Pratiwi, T.C.R dan Widiyastuti, T. (2018). Analisis Citra Perusahaan Terhadap Keputusan Pembelian Motor Merek Yamaha di CV Alvina Indah Motor Blitar. Jurnal Penelitian Manajemen Terapan (PENATARAN), Vol. 3, No. 2.

Schiffman, L dan Kanuk, L.L. (2008). Perilaku Konsumen. Jakarta: PT. Indeks.

Setiadi, Nugroho J. (2015). Perilaku Konsumen. Jakarta: Kencana.

Stanton, W.J (2008). Prinsip Pemasaran. Jakarta: Erlangga.

Steinmetz, Lawrence L. (2011). How to Sell at Margings Higher than Your competitors. University of Michigan. 
Sugianto, R dan Ginting, S.O. (2020). Analisis Pengaruh Harga, Kualitas Produk, Lokasi, Fasilitas Dan Promosi Terhadap Keputusan Pembelian Rumah Pada Perumahan Medan Resort City. Jurnal Wira Ekonomi Mikroskil : JWEM, Volume 10, Nomor 01.

Sumayang, L. (2003). Dasar-dasar Manajemen Produksi dan Operasi. Jakarta: Salemba Empat.

Sunyoto, D. (2015). Perilaku Konsumen dan Pemasaran. Yogyakarta: CAPS (Central of Academic Publishing Service).

Tjiptono, F dan Chandra, G. (2016). Service, Quality \& satisfaction. Yogyakarta: Andi.

Zhang, Yang. (2009). A Study of Corporate Reputation's Influence on Customer Loyalty Based on PLS-SEM Model. International Business Research. 